\title{
Stock Volatility in Muscat Securities Market
}

\author{
Nadia Sha, K.S. Chandrasekar, M.R.Dileep, Shariq Mohammed
}

\begin{abstract}
Research studies proved that share prices keep on changing every day in the stock markets. Hence this particular research article is very relevant to analyse the Volatility of Muscat Securities Market over a specified period. Here, six Oil and Gas companies were selected for this research article. The study aimed at analysing the stock market volatility of Regular market players and Parallel market players of Muscat Oil and Gas companies and evaluating their relationship.This research article used GARCH model for measuring the volatility of Muscat Securities Market with special reference to Oil and Gas companies listed in the MSM.

The study resulted that highest volatile companies are Shell Oman Marketing from regular market and Oman Oil Market from parallel market. Study also found that National Gas and Shell Oman Marketing companies has the probability of producing positive return and Almaha Petroleum Products Mar. Study also found that positive shock has higher level of impact on conditional variance while connected with negative shock.

From the Parallel market it is found that Muscat Gases has the probability of positive return in future. Based on the descriptive result it is found that there are two companies i.e., National Gas and Shell Oman Marketing were expecting positive return in future. Therefore, investors can focus to these companies while they enter into the Muscat stock market, Study found that there is no significant price variation between the three regular market companies.
\end{abstract}

Keywords : Volatility, Muscat Securities Market, Oil and Gas companies, Stock Volatility, stock market,GARCH model, E-GARCH model

\section{INTRODUCTION}

The financial market and stock market is an indicator of the economic growth of a country and it is assumed as a vital part in a nation's monetary policy and moreover used as an indicator of the stability of an economy. Stability of the stock market's performance is the base stone of every countries economic policy. Hence the stock market stability and its volatility have been concerned as a development indicator. Therefore, all countries have been encouraging share trading and monitoring the activities of listed companies in the stock market. Many studies have proven that various factors have been affecting the stock market price fluctuations i.e., Internal and External factors. In some time, some of the news, events like financial crisis, political events, policy changes etc. are

Revised Version Manuscript Received on 16 September, 2019.

* Correspondence Author

Dr. Nadia Sha, Assistant Professor, CCBA, Dhofar University, Salalah, Sultanate of Oman,

email: nsha@du.edu.om, nadia.nadsnads@gmail.com

Dr. K.S. Chandrasekar,Professor and Dean, IMK, University of Kerala, Trivandrum,

Email: kscnair@gmail.com

Dr. M.R.Dileep, Head-Department of Travel and Tourism Management, Pazhassiraja College, Wayanad, Kerala, India.

Email: dileepmadhav@gmail.com

Dr. Shariq Mohammed,Assistant Professor, CCBA, Dhofar University, Salalah, Sultanate of Oman.email: smohammed@du.edu.om affecting the stock market price fluctuations. Normally historical price indices and historical performance of stock market at different situations are used to predict the stock market volatility in long run. Here the study was focussed with the Muscat stock market (Both Parallel and Regular Market) and asymmetric GARCH and Exponential EGARCH models used to predict the Muscat Stock Market Volatility and Traditional One Way ANOVA and Bayesian t-test were used to identify the significant difference among the companies and between parallel market.

\section{HISTORY OF MUSCAT STOCK MARKET}

The stock market of Oman is Muscat Securities Market (MSM), which is the only one in the whole Oman and started its journey on $21^{\text {st }}$ June 1988 . The MSM was enacted with a Royal Degree of 53/88 in the year 1988. The MSM was established basically to regulate and control the securities market of Oman. With two Royal Decrees the stock Market has been re-established after successful ten years,

\section{A. Stock Market Volatility}

It is simply an up and down drift of the stock market. The commonwealth financial network has explained the stock market volatility through a simple example i.e., volatility is similar to premiums of car insurance which increases laterally with the chance of risky circumstances, that is, a person with very poor past record of driving or parking the car in a place where there is a threat of robbery. Hence it can be concluded that volatility is a market situation and it is simply referring to investors nervousness and many analysts believe that increase or decrease in the volatility can indicate a rebound i.e., many reasons have been affecting the stock market volatility.

\section{B. Review of Literature on stock volatility and different models.}

Literatures were many related to the study on stock volatility and different models to check the same, some of them are listed as follows:

Prabhakaran (2017) has also analysed stocks in MSM to check its volatility. The study has select 6 companies. The study focused with the volatility. Study has conducted an analysis positive and negative shock impact among the companies by using GARCH models. Study found that selected companies have long term volatility.

Tamilselvan\&ShaikM.,V. (2016), conducted a study in related to predicting stock market instability in which significance indication from MSM were received. The study has used four active trading indices from Muscat Stock Market and their study period was January 2001 to November 2015. The study found that volatility is highly determined and anirregularity was found between the return shocks and

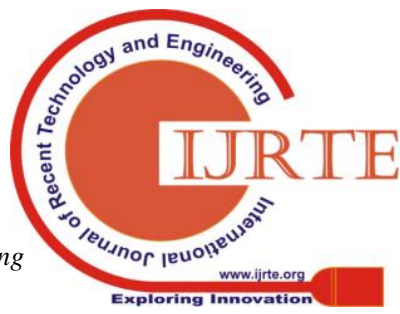


volatility adjustments. They suggest formulating an investment strategy with the help of the past data available in stock market and through that predictions can be practiced. Hazem A. S and Mohamed K.A.J (2015) studied the volatility on stock return in connection with the volume of trade of shares seen in MSM listed industrial firms; which resulted in a positive relation between the selected variables as propounded in weal form of the EMH.

Qamruzzaman (2015) found an empirical evidence of volatility clustering from Chittagong stock exchange and the study collected data from 04 January 2004 to14 September 2014. Here also EGARCH model were used and claim that these models were able to understand the different trends of particular stock exchange.

Qiang Zhang (2015) has made an analysis regarding the impact of the financial recession happened in the economy in the study period in the stock markets in Hong Kong and China. The study found comparing with the pre-crisis period and the crisis period more volatility was shown in crisis the particular crisis period.

Neha Saini (2014) analyse the capacity of ARMA by applying instability checking models in predicting stock markets in India. The study has collected the data from BSE (Bombay Stock Exchange) in daily basis and came to a conclusion that the tools used to predict the volatility in the present study are very much capable of predicting the stock market volatility.

Nalina, K. B. (2014) has studied about the Indian stock market volatility. The study has focused with volatility of aggregate market indices using traditional method, disaggregated volatility and the connection between some variables in macroeconomic and industry, market and some firms. Study found that the investors in Indian stock markets are rational as the slight information with regard to politics or economy will give a huge jumps in the line graph.

Prashant Joshi (2014) has made a stock market volatility study at Bombay stock market and the study focussed on Bombay Sensex and collected data for a period covering 4 years only that is from 2010-2014. The study established presence of volatility and leverage effect of course adding to a behaviour of reverting feature and clustering of volatility. The study has used various GARCH models whereby supporting the evidences for the findings.

PotharlaSrikanth (2014) has used two popular GARCH for modelled a asymmetric nature of volatility. The study used GARCH models are GJR-GARH model and PGARCH. The data for the study covered over 15 years that is from 1997-2013 and the outcome presented that the stock market has the effect of leverage. Again it establishes a periodic cycle effect in the volatility condition in the stock market under study.

Shah. P., et.al (2014) examines the post facto effect of merger and acquisition and the study show that post announcement return is significant on samples selected. The study cannot signify the strong form of efficiency on study period.

Qiu. L. (2014) the study evaluates the intensity of the difference in returns of S\&P 500 companies which were declared in quarterly basis. It also reveals the factors that create this difference in return in this security. It says that the fluctuating result for the return was because of the shift of apt control and supervision with the amount of earnings surprises. Imelda et.al (2014) Studied the abnormal returns and trading volume in relation with presidential election in Indonesia stock market. The study focuses on sectorial indices and studied the difference between abnormal return and trading volume. Study revealed strong evidence for difference in abnormal return before and after the president election.

Fereshteh Hossein (2013) has conducted an investigation among some selected group in pharmaceutics, some in vehicle and in oil industry. Here again the study used GARCH models to forecast the volatility in stock markets, where it found positive effect of volatility on pharmaceutical group and negative effect in oil groups.

Mohandass (2013), conducted a study in related to best fit model for measuring volatility. Data were collected from Bombay Stock Exchange from 2001, January to 2012 June. Study found that model is right to measure the instability in the series of return. Hence, study suggest to practice GARCH $(1,1)$ model, also claim that this model is the best one.

Naliniprava(2013) has used various GARCH models again but the forecast was done for stock markets in six fast growing countries and collect the data or indices from the date extending for 10 years which was from 1999 January to 2010 May. In this study as they conducted a comparison study between the stock markets of the countries they find a difference with Brazilian stock market alone, where it showed a positive effect among stock return and risk. Again they proved that the shocks do give a volatility effect to all the stock markets irrespective of countries. The study also used GARCH models to give proof on the irregularity in stock returns among the six countries selected for the study. It concluded that the return series do have leverage effect.

Yung-Shi Liau (2013) has given proof on the fact that the bad news have more effect on the instability of the market during the passing of crisis period. Their study has focussed on instability during the financial crisis in Asia and collected data from seven Asian countries security market and found that bad news in stock market is very sensitive and it will badly affect the stock markets.

Rakesh Gupta (2012) has used asymmetric APARCH model for forecasting the instability of stock markets of those countries who are the founding members of the ASEAN.

Jonson .L.,(2011) the study focus on news announcement effect on the sector indexes returns. This study has attempted to evaluate the correct response of the returns announced by OPEC. The study used on the behaviour of sector indexes returns of the stock market. In order to estimate exact reaction of index return after OPEC announcement and author uses extended version of normal return models.

Praveen (2011) has studied the data various lots of shares in stock market like, BSE 200, , BSE SENSEX,BSE 100 CNX NIFTY,BSE 500 etc. for almost 14 year ranging from

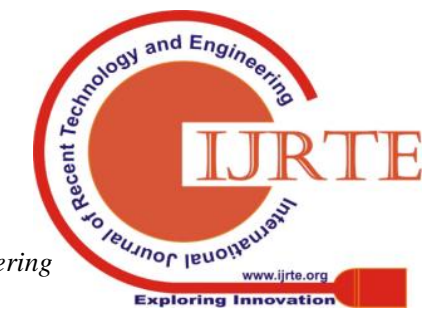


2000-2014 and used the GARCH and ARCH model to determine the irregularity in financial markets of India. The study determinedthat the financial market in India has affected drastically with the crisis for a very long period. Suman. (2011) has focused with stock market volatility of five developing countries namely Brazil, Russia, India, China and result of day of the week outcome in stock market return and instability. Study found that markets increase and decreasetimely, but the Investor should have systematic investment plan, which is one of the most efficient ways to benefit from the volatility.

Banamber et.al.,(2010) has studied the stock markets in Japan and India, about the stock market volatility dynamics using TGARCH $-\mathrm{M}$ model. They found that the markets are affected asymmetrically along the bad news and good news. The volatility in returns of the securities is presents in both the countries.

Jibendu Kumar (2010) has applied different GARCH models for forecasting volatility and collected data of indian stock markets like NSE and BSE. It collected 14 years of data for testing the volatility. It came to a conclusion thet the stock markets did not show a ny difference with any of the GARCH models used in the study.

James, W. Pynnonen,K.S., (2010) observed that there is very low cross correlation among abnormal return and it caused to over rejection of true null hypothesis.

Liua. J. et.al (2010) studied the role of stock market in emerging economy and result indicates that investment decisions are predominantly determined by firm characteristics.

Ravichandran, V. and Khalid Abdullah Alkhathlan (2010) studied about the influence of prices of oil on stock market of Gulf countries. The study has used GARCH-M model for identifying the impact. The result shows an effect in GCC stock markets with the changes in price of the oil for a longer period. The study also defined the word 'Long Term'.

Amit Kumar (2009) has used Autoregressive Conditional Heteroskedastic models and Exponential GARCH model for investigating the volatility of NIFTY and Sensex and came to a conclusion that EGARCH is one of the efficient model to check the instability and thereby performance of the stock is predicted.

Hirvonen. J., (2009) throughout the current years, the venture activity of Finnish companies to Russia has plainly taken off. Various Finnish companies have established Russian operations, namely acquisition and merger, to come into the Russian Federation in to seek for premature stage market with elevated income. Most recently, establishing of Russian operations has turn out to be a fashion in the midst of the Finnish companies, although the present demanding financial states of affairs seem to have condensed this fashion. A few Finnish companies have going ahead of functioning in Russia previously in the early 80 s and are still increasing their operations in the Russian markets. These companies have introduced a pioneering technique of supervising their big business and functioning in the markets, when compared to Mexico (BRICM). The study result provides and empirical

the counterparts at the Russian markets. This has given the company's aggressive improvement in their businesses. Conducted study on Merger and acquisition of Finnish companies to Russian markets. The finish companies are following innovative method for business operation compared to counterparts to Russian markets. The study examines abnormal performance of Finnish companies when these introduced to the market.

Dima Alberg and Haim Shalit (2008) used GARCH and EGARCH model for analysing conditional variance and mean return of (TASE). The study result indicated that the GARCH asymmetric model having a fat-tail increases the chance of estimation for calculating the conditional variance and also claim that to predict the TASE components, EGARCH method along with the t-test (skewed) will be the most apt one.

Floros, Christos (2008) also tried the effect of GARCH methods in describing the risk in financial market. The study used these methods in countries like Egypt and Israel by taking the data in a daily basis from TASE -100 andCMA General Index.It also contradicts to the risk-return trade off principle, that; by increasing of risk factor in the stock will not always give increase in returns.

Kumar S. (2006) took the stock market in India as well as Forex market to study the instability of the stock market. It used various models pertaining to statistics and econometrics to evaluate its ability to predict. It concluded that EW.1 L4 methods and G.-I RCH 11. I methods can help the Indian stock market and the forex market to give a perfect prediction. As both the markets has shown an equal result the study makes a meaning in this field.

Banerjee, A. and Sarkar, S. (2006) have used GARCH type models for predicting the volatility in NSE. It followed a rare model to collect the daily data that is in a five-minute interval basis. The result indicated that GARCH model types predict themarket better than a usual volatility models. It also commented that asymmetrical model is better than symmetrical model in respect to GARCH model.

Acquisti, A. et.al (2006) observed that security prices are influenced by stock split and found that companies generally efficient but not perfectly to the stock split announcement. Glen R. (2005) attempted to study the contribution of the volume of trade in a stock market with the rising forecasts of volatility by using various models like $\mathrm{ARCH}$, option and combination models. It came to a conclusion that the role of volume of trade is being changed in relation with the forecast of volatility to be depict a stable value to an estimate which is looking forward.

Hock Guan Ng (2004) applied GARCH models for predicting the values of the selected stocks in the study and it concluded that they are performing in better way to the Risk Metric Models and they reveals that forecasting performance is based on the data set used in the study

Published By:

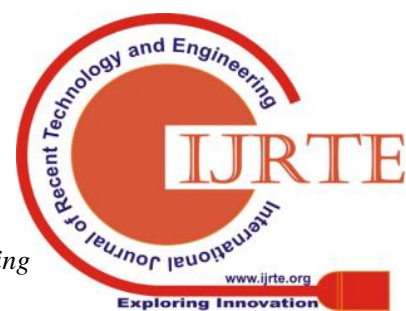


Eberhart, A.C et. al (2004) studied effect on stock split on merger and acquisition and found abnormal return around announcement. Results showed positive abnormal return associated with announcement related split on share price. Andrade, G., et.al (2001) studied merger announcement and found that significant abnormal return on merger announcement and significant change in volume activity.

Binder. J.J., (1998)11 observed that stock split happened in multiple times and found abnormal return around announcement time.

Brad M, et.al (1997) studied the reaction of stock price on dividend announcement and author used cross sectional analysis on prices of shares. The result found there is no statistical significant for dividend announcement.

Frooman. J., (1997) conducted study on daily stock returns and they examined the difficulty of daily stock return characteristics. The test results ignoring cross sectional dependence of data and also studied the properties of daily stock return with respect to event study methodology.

Philip (1996) has also tested the estimating power of the GARCH model in the irregularity of stock market values. The study used five countries stock markets like Netherland, Sweden, German stock market, Italy and Spain from 1986-1994 that is nine years of data collection which is a good amount of value. It resulted that QGARCH can be utilised for a situation were great deviations in the values are not seen like some financial crisis year where crash of stock markets is occurred.

Agrawal, J.et.al (1995) they found excess return on stock exchanges out of stock split information and showed stock split are associated with positive abnormal return on study period. Observation suggests that there is a positive return and it does not follow any pattern.

Armitage. S., (1995) observed that there is no abnormal return on post period revealed to merger announcement and regression analysis shows that no significant change in post-merger period and observed that abnormal return evident form stock split day before announcement.

Coutts A. J et.al (1995) examined the stock split information on share price and it caused to increase shareholders compared to non-split companies.

Glosten, L. (1993) has used modified GARCH-M model for estimating the irregularity in market. It stated that a result in volatility, if it is showing a monthly, may not be persistent. Also it continued by stating that if the unanticipated returns seem to be positive then it shows a descending review and if the unanticipated returns seem to be negative then it shows an ascending review.

Nelson (1991) has made a remarkable change in the old GARCH model keeping its same intensity of flexibility and simplicity. The study introduced a new array of ARCH model particular study. This study went out of the box and attempted to rebuild the models used basically in estimating the stock values.

Corrado. C.J (1989) studied stock market split information does not create any effect on perfect capital market. He explained that changes on depository receipts not associated with stock split and found that information effect on liquidity of stocks.

Akgiray, V. (1989) used GARCH model for predicting the stock market volatility and collected data for the period extending from 1963-1986 almost 23 years, which is a big data to check the reliability of the model which is used in the study. It also evaluated the time series behaviour of the stock value in a daily basis. The study also praised the effectiveness of GARCH model when comparing with the linear white noise model.

Malatesta, P.H (1986) evaluated the merger and acquisition effect on share prices of companies and the firms under study found the significance in return on stock split.

Bollerslev (1986) has found that changing the ARCH to GARCH model is resembling the change of standard time series to the general process (ARMA). The study found that, it certifies a more tight-fisted explanation in many conditions.

Brown. S.J et.al (1985) examined that stock split effect relatively new concept and result shows negative effect on price and return around event date. The overall returns after the stock split are negative.

Thompson R (1985) studied stock market split information does not create any effect on perfect capital market. He explained that changes on economic event not associated with stock split and found that information effect on liquidity of stocks. Studied on reflection of stock split on receipts and found that stock return mostly negative irrespective of stock split.

\section{Conclusion of Review of Literature}

The review of literature of different studied conducted in the area of stock market volatility have been providing enough evidence regarding the performance of different type of GARCH models and also indicates that recent historical data and information are affecting the stock market volatility and some of them argue that systematic investment plan is one of the most efficient ways to benefit from the volatility (Suman, 2011), election result will affect the volatility (Imelda et.al, 2014), also stated that during the periods of vital economic and political changes in the economy.

(Nalina, K. B. (2014), markets are affected with asymmetrically along the bad news and good news-argued by Banamber (Banamber et.al.,(2010) and Brad M, et.al found that dividend announcement is not influencing stock market price fluctuation (Brad M, et.al, 1997). Another study indicates that changes on economic event not associated with stock split and found that information effect on liquidity of stocks (Thompson R, 1985). Hence it could be seen from prior studies that stock market is influenced by the information available at the current situations and unexpected situations and events are associated with the volatility of stock market 
The review of literature has also providing the justification for using GARCH and EGARCH in the present study. Many studies were indicating that different types of GARCH models are better for predicting the stock market volatility. Amit Kumar found that EGARCH is a proven model for the same (Amit Kumar, 2009). Dima Alberg and Haim Shalit claim that a fat-tailed GARCH model which is asymmetric gives a positivity which is greater than any other situation for predicting the measurement of the conditional variances. It again proved that by including the skewed t-test along with EGARCH model makes the TACE indices to forecast successfully. (Dima Alberg and Haim Shalit, 2008). Akgiray, V. claim that GARCH models are superior in forecasting volatility (Akgiray, V. (1989) and GARCH lettingelastic lag structure (Bollerslev, 1986). Based on the review of prior studies, researcher has decided to use GARCH model and EGARCH model for analysing the stock market volatility of Muscat Stock Exchange.

\section{OBJECTIVES OF THE STUDY}

Analysing the stock market volatility of Regular market players of Oil and Gas companies in MSM

To analyse the stock market volatility of Parallel market players of Oil and Gas companies in MSM

To evaluate the relationship between Regular market players and Parallel market players of Oil and Gas companies listed in MSM.

\section{MATH}

Muscat Securities Market has provided with all the financial information needed for the data in this study. Here the study has selected three companies in oil and Gas category from the Regular market and from Parallel market another 2 companies were selected. i.e., National Gas (NGCI), Almaha Petroleum Products Mar (MHAS), Shell Oman Marketing (SOMS) companies from Regular market. Muscat Gases (MGMC), and Oman Oil Marketing (OOMS) from Parallel Market. Two companies were excluded i.e., Oman Oil Marketing Pref. Shares (OOMP) and Shell Oman Mark. Pref. Shares (SOMP) because of non-availability of data (Stock price).

\section{A.Tools used for Analysis}

The tools applied for this study are:

- Descriptive Statistics

- $\operatorname{GARCH}(1,1)$ Model

- EGARCH Model

- Unit Root Test

- One Way ANOVA

- Bayesian Independent Sample t-test

SPSS and MS Excel, and E Views software were used to analyse the collected data.

\section{GARCH(1,1) AND EGARCH}

GARCH model has been described as $\operatorname{GARCH}(1,1)$ The $(1,1)$ in brackets were the notations are standard shows its first numerical value the intensity of autoregressive lags or the equation appearing in the $\mathrm{ARCH}$ terms. The second in the brackets is the GARCH terms in numbers that means the number of moving average lags (Robert Engle, 2008). These values never become completely zero with having a declining weights. The applicability of this model is a past squared residuals' weighted aversage. Ungenerous models are given which are easy to predict and also proved to be a successful model to estimate the conditional variances. This is also known because of its simplicity in explanations (Bollerslev, 1986). The forecast which is in distant horizon will always be same irrespective of time period. This is just unconditional variance; hence it could be say that they are mean relapsing and provisionally heteroskedastic with a continuousunrestricted variance. The $\operatorname{GARCH}(1,1)$ model is enough which is the best benefit of this model as it is usually much more ungenerous and also it includes many information as in ARCH models which are very large in its data or large numbers of lags.

Then comes the next model called the EGARCH model which was propounded by Nelson (1991) during 1992 Cao and Nelsondebate that non-negativity limits in the linear GARCH model are too limiting. For EGARCH model there is no boundaries on the factors in comparing to the GARCH model which imposes the nonnegative constraints on the parameters.

\section{ANALYSIS OF DATA COLLECTED AND INTERPRETATIONS:}

Below are the tables prepared with collected data from MSM. Table below is depicting the selected companies' mean and standard deviation during the period - December 2016 and November 2017. The mean and standard deviation is highest for Shell Oman Marketing (SOMS) from regular market and mean and std. Deviation is highest for Oman Oil Market (OOMS) from parallel market. Hence it can be inferred that selected companies were more volatile; the highest volatile company is Shell Oman Marketing (SOMS) from regular market and Oman Oil Market (OOMS) from parallel market. National Gas (NGCL) and Shell Oman Marketing (SOMS) companies' skewness shows positive (0.0614 and 0.7651), this indicate that these two companies has the probability of producing positive returns and Almaha Petroleum Products Mar (MHAS) company have negative skewness (-4.42), this indicate that the probability of negative return in future. Whereas the Muscat Gases (parallel) has skewness value was positive, thus it can be inferred that the probability of positive returns with regard to this companies. The Oman Oil Marketing (OOMS)skewness value was negative (-1.791), thus there is a probability of negative returns in future. The Almaha Petroleum Products Mar (MHAS) Kurtosis was above the cut off i.e., $3<20.95$, the distribution nature is Leptokurtic as it is normal distribution. Whereas the other two companies from regular market i.e., National Gas (NGCI) and Shell Oman Marketing (SOMS) have negative Kurtosis, hence it can be concluding that distribution is abnormal and the distribution nature is Platy kurtic. A look at the parallel market two companies Kurtosis was positive and below the cut off (Kurtosis < 3), thus the distribution nature is meso kurtic. 
Table 1: Descriptive Statistics of the companies selected.

\begin{tabular}{|c|c|c|c|c|c|c|}
\hline & Name of Company & Mean & SD & Std. Error & Kurtosis & Skewness \\
\hline \multirow{3}{*}{ 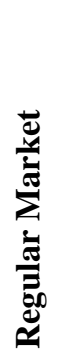 } & $\begin{array}{l}\text { Almaha Petroleum Products Mar } \\
\text { (MHAS) }\end{array}$ & 0.93296 & 0.380 & 0.0360 & 20.95 & -4.42 \\
\hline & National Gas (NGCI) & 0.28776 & 0.388 & 0.001765 & -1.31335 & 0.0614 \\
\hline & Shell Oman Marketing (SOMS) & 1.7272 & 0.685 & 0.0057 & -0.35845 & 0.7651 \\
\hline \multirow{2}{*}{ 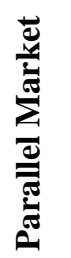 } & Muscat Gases (MGMC) & 0.54804 & 0.324 & 0.0048 & 1.1568 & 0.520 \\
\hline & Oman Oil Marketing (OOMS) & 1.4524 & 0.547 & 0.0029 & 1.571 & -1.791 \\
\hline
\end{tabular}

Table above is depicting the selected companies' mean and standard deviation during the period - December 2016 and November 2017. The mean and standard deviation is highest for Shell Oman Marketing (SOMS) from regular market and mean and std. Deviation is highest for Oman Oil Market (OOMS) from parallel market. Hence it can be inferred that selected companies were more volatile; the highest volatile company is Shell Oman Marketing (SOMS) from regular market and Oman Oil Market (OOMS) from parallel market. National Gas (NGCL) and Shell Oman Marketing (SOMS) companies' skewness shows positive (0.0614 and 0.7651), this indicate that these two companies has the probability of producing positive returns and Almaha Petroleum Products Mar (MHAS) company have negative skewness (-4.42), this indicate that the probability of negative return in future.
Whereas the Muscat Gases (parallel) has skewness value was positive, thus it can be inferred that the probability of positive returns with regard to this companies. The Oman Oil Marketing (OOMS)skewness value was negative (-1.791), thus there is a probability of negative returns in future. The Almaha Petroleum Products Mar (MHAS) Kurtosis was above the cut off i.e., $3<20.95$, the distribution nature is Leptokurtic as it is normal distribution. Whereas the other two companies from regular market i.e., National Gas (NGCI) and Shell Oman Marketing (SOMS) have negative Kurtosis, hence it can be concluding that distribution is abnormal and the distribution nature is Platy kurtic. A look at the parallel market two companies Kurtosis was positive and below the cut off (Kurtosis < 3), thus the distribution nature is meso kurtic.

Table 2: Unit Root Test for companies selected from Regular Market and Parallel Market

\begin{tabular}{|c|c|c|c|c|c|}
\hline $\begin{array}{l}\text { Stock } \\
\text { Market }\end{array}$ & Test & $\mathbf{I} \& \mathbf{T}$ & MHAS & NGCI & SOMS \\
\hline \multirow[b]{2}{*}{$\begin{array}{l}\text { Regular } \\
\text { Market }\end{array}$} & \multirow{2}{*}{$\begin{array}{l}\text { Augmented } \\
\text { Dickey Fuller } \\
\text { Test }\end{array}$} & Intercept & -11.678 & -12.543 & -13.653 \\
\hline & & Trend & $\begin{array}{l}-11.587 \\
(\text { Both }=-11.682)\end{array}$ & $\begin{array}{l}-12.473 \\
(\text { Both }=-12.548)\end{array}$ & $\begin{array}{l}-13.656 \\
(\text { Both }=-13.658)\end{array}$ \\
\hline $\begin{array}{l}\text { Stock } \\
\text { Market }\end{array}$ & Test & $\mathbf{I} \& \mathbf{T}$ & MGMC & OOMS & \\
\hline \multirow[b]{2}{*}{$\begin{array}{l}\text { Parallel } \\
\text { Market }\end{array}$} & \multirow{2}{*}{$\begin{array}{l}\text { Augmented } \\
\text { Dickey Fuller } \\
\text { Test }\end{array}$} & Intercept & -13.984 & -11.546 & \\
\hline & & Trend & $\begin{array}{l}-13.982 \\
(\text { Both = -13.986) }\end{array}$ & $\begin{array}{l}-11.552 \\
(\text { Both }=-11.556)\end{array}$ & \\
\hline
\end{tabular}

Source: MS Excel; The P value at $1 \%$ for ADF Test for intercept, trend

Table 2 shows the intercept and trend of selected companies from regular market and parallel market for finding the Unit root of the data series. The critical values are 3.2543 for intercept, -2.3984 for trend and -3.45690 for both. Hence it can be inferred that the values for the companies selected from regular market and parallel market were having stationarity and the t-test statistics values are less than the at 1 per cent significant level. Hence the null statement is there is no stationarity in the identified data stands rejected and unit root test result indicate that stock price returns are stationary for the selected companies from regular market and parallel market.

\section{A. $\operatorname{GARCH}(1,1)$ Model}

Regular Market Companies

Three companies were selected from regular market. The company like Almaha Petroleum Products Mar (MHAS) $(\alpha 0=0.0032 \quad$ (2.627), $\quad \alpha 1=0.2340(2.845) \quad$ and $\beta 1=0.2753(1.2456)$ ) having coefficient of $\beta 1$ is not large, hence it can be inferred that there are no long term volatility with regard to MHAS company. Whereas the rest of the two regular market company (GARCH $(1,1)$ Model) coefficient of $\beta 1$ is vast; indicates the long term volatility with regard to these two companies. 
The companies estimated model values are National Gas= $\alpha 0=0.0002$ (3.8845), $\alpha 1=0.0965$ (4.56720) and $\beta 1=0.8432$ (18.3457) and Shell Oman Marketing $=\alpha 0=0.0032$ (3.5231), $\alpha 1=0.2378(3.8231)$ and $\beta 1=0.7231(8.3210)$

Parallel Market

Two companies were selected from parallel market. The Muscat Gases company coefficient of $\beta 1$ very large i.e., $\alpha 0=0.0002 \quad(3.542), \quad \alpha 1=0.2224 \quad$ (3.8823) and $\beta 1=0.7245(5.3219)$, hence it can be inferred that there is a long term volatility with regard to this company, whereas the Oman Oil Marketing having coefficient of $\beta 1$ is not much large i.e., $\alpha 0=0.0004$ (2.6689), $\alpha 1=0.7732$ (3.8823) and $\beta 1=0.2214$ (1.3219), hence it cannot ensure long term volatility.

Table 3: GARCH $(1,1)$ Model

\begin{tabular}{|c|c|c|c|c|}
\hline $\begin{array}{l}\text { Company } \\
\text { Name }\end{array}$ & Estimated model with values & $\alpha \mathbf{j}+\beta \mathbf{i}$ & AIC & $\begin{array}{l}\text { Log } \\
\text { Likelihood }\end{array}$ \\
\hline MHAS & $\begin{array}{lllll}\alpha 0=0.0032 \quad(2.627), & \alpha 1=0.2340 & (2.845) \quad \text { and } \\
\beta 1=0.2753(1.2456) & & & \end{array}$ & 0.5093 & -2.3452 & 334.873 \\
\hline NGCI & $\begin{array}{l}\alpha 0=0.0002 \quad(3.8845), \quad \alpha 1=0.0965(4.56720) \quad \text { and } \\
\beta 1=0.8432(18.3457)\end{array}$ & 0.9397 & -2.0341 & 332.654 \\
\hline SOMS & $\begin{array}{lllll}\alpha 0=0.0032 \quad(3.5231), & \alpha 1=0.2378 \quad(3.8231) \quad \text { and } \\
\beta 1=0.7231(8.3210) & & & \end{array}$ & 0.9609 & -2.4325 & 338.543 \\
\hline MGMC & $\begin{array}{llll}\alpha 0=0.0002 \quad(3.542), & \alpha 1=0.2224 & (3.8823) \quad \text { and } \\
\beta 1=0.7245(5.3219)\end{array}$ & 0.9469 & -3.8734 & 446.882 \\
\hline OOMS & $\begin{array}{lllll}\alpha 0=0.0004 \quad(2.6689), & \alpha 1=0.7732 & (3.8823) & \text { and } \\
\beta 1 & =0.2214(1.3219)\end{array}$ & 0.9946 & -3.9932 & 442.567 \\
\hline
\end{tabular}

Source: Computed from MS Excel and xlstat

The coefficient of $\beta 1$ is close to 1 with regard to two companies from regular market i.e., National Gas (NGCI) and Shell Oman Marketing (SOMS) and one company from parallel market i.e., Muscat Gases (MGMC). Hence it can be assumed that the new stock of these companies does not have an impact on prices for a long period and Almaha Petroleum Products Mar and Oman Oil Marketing companies' coefficient is not close to 1 , hence it can be inferred that new stock of these two companies have an impact on prices for a long period

The volatility persistence $(\alpha j+\beta i)$ of the selected companies from both regular and parallel market shows that values are close to one hence it can be inferred that any shock to volatility is permanent which means greater persistence of any shock to return.

Table 4: EGARCH Model

\begin{tabular}{|c|c|c|c|c|c|c|}
\hline \multirow{2}{*}{$\begin{array}{l}\text { Name of the } \\
\text { Company }\end{array}$} & \multicolumn{4}{|c|}{ Values in Estimated model } & \multirow{2}{*}{ AIC } & \multirow{2}{*}{$\begin{array}{l}\text { Log } \\
\text { Likelihood }\end{array}$} \\
\hline & $\alpha 0$ & $\alpha 1$ & $\beta 1$ & $\gamma 1$ & & \\
\hline MHAS & $\begin{array}{l}-1.3485 \\
(-2.3331)\end{array}$ & $\begin{array}{l}-0.4023 \\
(-2.4361)\end{array}$ & $\begin{array}{l}-0.1532 \\
(-3.4682)\end{array}$ & $\begin{array}{l}0.7319 \\
(5.8931)\end{array}$ & -2.3945 & 336.733 \\
\hline NGCI & $\begin{array}{l}-10.3267 \\
(-8.4312)\end{array}$ & $\begin{array}{l}0.5214 \\
(2.9985)\end{array}$ & $\begin{array}{l}0.2075 \\
(3.0024)\end{array}$ & $\begin{array}{l}0.4214 \\
(3.4521)\end{array}$ & -3.7831 & 338.510 \\
\hline SOMS & $\begin{array}{l}-11.3211 \\
(-12.4213) \\
\end{array}$ & $\begin{array}{l}0.6231 \\
(3.6753)\end{array}$ & $\begin{array}{l}0.6321 \\
(3.5218)\end{array}$ & $\begin{array}{l}0.6791 \\
(4.3215)\end{array}$ & -3.5892 & 340.412 \\
\hline MGMC & $\begin{array}{l}-10.4210 \\
(-3.7328) \\
\end{array}$ & $\begin{array}{l}0.4318 \\
(3.4284) \\
\end{array}$ & $\begin{array}{l}0.6893 \\
(3.2164) \\
\end{array}$ & $\begin{array}{l}0.3920 \\
(3.384) \\
\end{array}$ & -3.6742 & 452.671 \\
\hline OOMS & $\begin{array}{l}-2.6729 \\
(-1.4321) \\
\end{array}$ & $\begin{array}{l}-0.3270 \\
(-3.571) \\
\end{array}$ & $\begin{array}{l}-0.8310 \\
(-2.5216) \\
\end{array}$ & $\begin{array}{l}0.6787 \\
(3.5810) \\
\end{array}$ & -2.6047 & 446.632 \\
\hline
\end{tabular}

Sources: Computed from Excel and xlstat.

Table shows the Exponential GARCH (EGARCH) result and it is observed that return series have shown significance constant coefficient for companies. For the companies from regular market and parallel market the EGARCH coefficients are less than one. It proves that the new surprises will not have a consequence on prices for a lengthier duration. Akaike's Information Criterion (AIC) values are very low hence it can be concluding that the present model is most likely right one. The coefficient result of ARCH effect is shows the highest for Shell Oman Marketing (SOMS) and lowest for Almaha Petroleum Products Mar (MHAS). The value of ARCH and GARCH coefficient of companies (Regular and Parallel Market) are found to be less than one, hence it can be inferred with longer determination of external surprises concerning return. The larger coefficient $(\mathrm{ARCH})$ stipulates less reaction of stocks related to new surprise events in the stock market, whereas the EGARCH result indicates that there is a increased effect for all the companies which are under study (Regular and Parallel Market). Hence it can be concluded that positive surprise events have higher level of impact on conditional variance while connected with negative surprise events in the stock market.

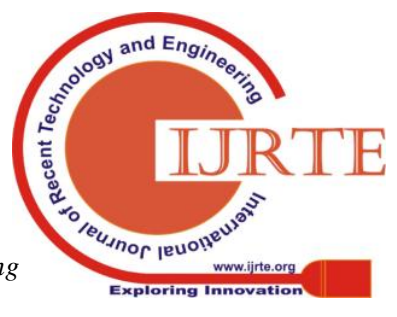


Stock Volatility in Muscat Securities Market

Table 5: Stock Price Variation between Selected Companies

\begin{tabular}{|c|c|c|c|c|c|}
\hline \multicolumn{6}{|c|}{ One Way ANOVA } \\
\hline Source of Variation & $S S$ & $d f$ & $M S$ & $\boldsymbol{F}$ & P-value \\
\hline Between Groups & 1.242355 & 1 & 1.242355 & 2.010011 & 0.09603 \\
\hline Within Groups & 1.057321 & 11 & 0.26433 & & \\
\hline Total & 2.299675 & 12 & & & \\
\hline & Average & Variance & & & \\
\hline Column 1 & 0.98264 & 0.519848 & & & \\
\hline Column 2 & 0.072565 & 0.008812 & & & \\
\hline
\end{tabular}

Table shows the ANOVA test. The result found that p-value $(0.09603)$ is greater than at 5 per cent significant level, hence it can be inferred that there is no significant variation between the selected regular market companies stock prices in the study period. Thus it can be concluding that selected three companies (Regular Market) price variation is almost same and failed to find the significant difference.

\section{Bayesian Independent Samples T-Test}

\begin{tabular}{lccccc}
\hline $\mathbf{t}$ & $\mathbf{n}_{\mathbf{1}}$ & $\mathbf{n}_{\mathbf{2}}$ & $\mathbf{B F}_{\mathbf{1 0}}$ & error \% & $\mathbf{p}$ \\
\hline-0.585 & 12 & 12 & 0.423 & 0.017 & 0.565 \\
\hline
\end{tabular}

Table shows Bayesian Independent sample t-test. The test result provides Bayes factor $\mathrm{BF}_{10}$ (in favour of alternative hypothesis statement) and the $\mathrm{p}$-value. Here the result displays that $\mathrm{BF}_{10}=0.423$ and $\mathrm{p}$-value $=0.565$. P-value designate that there is no important difference between the stock price of two companies (Parallel Market) i.e., 0.565> 0.05 . Bayes factor result explanation is shown under the figure 1

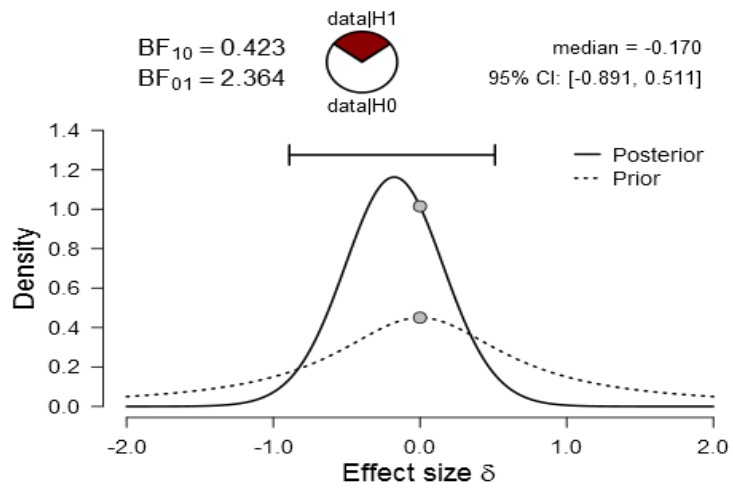

Figure 1:Figure shows the Bayes factor result (both alternative and null statement). Here the result indicates that $\mathrm{BF}_{10}=0.423$ indication in favour of important difference and $\mathrm{BF}_{01}=2.364$ in favour of no important difference. Hence it can be inferred that there is no important difference between the stock prices of two companies (Parallel Market) i.e., $1 / \mathrm{BF}_{10}$ $=2.364\left(\mathrm{BF}_{01}\right)$ and the Credible interval is $-0.891,0.511$. This indicate that there is a possibility between credible interval value i.e., $-0.891 \ldots \ldots . .0 . . . . . . .0 .511$. Hence the difference is not significant.

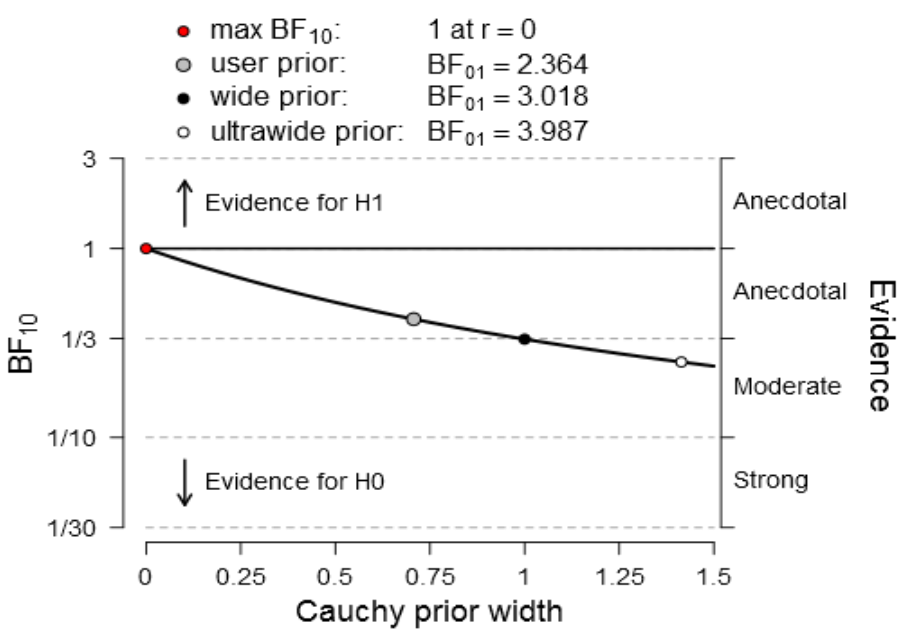

Figure 2: The figure shows the Cauchy prior width; this figure illustrates the evidence in favour for no difference $\left(\mathrm{BF}_{01}=2.364\right)$. The slop line end at the moderate evidence, hence it can be inferred that $\mathrm{BF}_{01}$ provide moderate evidence in favour of no difference.

\section{MAJOR FINDINGS}

Study found that highest volatile companies are Shell Oman Marketing (SOMS) from regular market and Oman Oil Market (OOMS) from parallel market. Study also found that National Gas (NGCL) and Shell Oman Marketing (SOMS) has a potential of providing with profitand Almaha Petroleum Products Mar (MHAS) has a potential of providing with lossin future. From the Parallel market it is found that Muscat Gases has the probability of positive return in future and Oman Oil Marketing (OOMS) has the probability of negative return in future. Based on the descriptive result it is found that there are two companies i.e., National Gas and Shell Oman Marketing (Regular market) were expecting positive return in future and from parallel market one company i.e., Muscat Gases were expecting positive return in future, therefore investors can focus to these companies while they entering into the Muscat stock market.

Study found that selected companies (Regular and Parallel market) stock price returns are stationary. Study also found that $\operatorname{GARCH}(1,1)$ Model coefficient of $\beta 1$ is large for two companies from regular market i.e., National Gas $(\beta 1=0.8432)$ and Shell Oman Marketing $(\beta 1=0.7231)$ having long term volatility. From the parallel market Muscat Gases $(\beta 1=0.7245)$ company coefficient 
of $\beta 1$ very large. This means that National Gasses has long term volatility in their stock prices. The EGARCH model coefficients are less than one for all companies from regular market and parallel market. Irrespective of other studies it gave evidence that new news which give shocks in market will not necessarily give an impact in MSM for a longer time period.

The GARCHand ARCH coefficient of companies (Regular and Parallel Market) are less than one according to the analysis; this proves the shocks in the market will be having the impact in the market for a longer period which is related to return. Study also found that negative shocks has very less impact compared to the positive shocks impact in the market.

Study found that there is no significant price variation between the three regular market companies, the ANOVA result is not significant $(0.09603>0.05)$

Bayesian Independent sample t-test was used to find the price difference between parallel market companies. Result indicate that evidence in favour of 'significant difference' was less than one i.e., $\mathrm{BF}_{10}=0.423$, simultaneously evidence in favour of 'No significant difference' was close to 3 i.e., $\mathrm{BF}_{01}=2.364$. Based on this result it can be concluded that between the stock prices of the two parallel market companies has no particular significant difference.

\section{REFERENCES}

[1]. Acquisti, A., Friedman, A., \&Telang, R., (2006). Is There a Cost to Privacy Breaches? An Event Study. Association for Information Systems, $\quad$ ICIS $2006 \quad$ Proceedings. 94 http://aisel.aisnet.org/icis2006/94

[2] Agrawal, J., \& Kamakura, W.A., (1995). The Economic Worth of Celebrity Endorsers: An Event Study Analysis. Journal of Marketing, 59(3), 56-62. DOI: 10.2307/1252119, https://www.jstor.org/stable/1252119

[3] Akgiray, V. (1989), "Conditional Heteroscedasticityin Time Series of Stock Returns. Evidence and Forecasts," Journal of Business, Vol. 62 (1),pp. 55-80.

[4] Amit Kumar Jha(2009)Predicting the Volatility of Stock Markets and Evidence, Case Study of NIFTY and SENSEX International Journal of Sciences: Basic and Applied Research (IJSBAR) ISSN 2307-4531

[5] Andrade, G., Mitchell, M.L.,\& Stafford, E., (2001). New Evidence and Perspectives on Mergers Harvard Business School Working Paper No. 01-070,HBS Finance Working Paper No. 01-07032 Pages Posted: 23 May 2001 , http://www.people.hbs.edu/estafford/papers/newevidence_perspective sonmergers.pdf

[6] Armitage, S., (1995)., Event study methods and evidence on their performance, https://doi.org/10.1111/j.1467-6419.1995.tb00109.x

[7]Banamber, M. \&Matiur, R., (2010). Dynamics of Stock Market Return Volatility: Evidence from the Daily Data of India and Japan, International Business \& Economics Research Journal, 9 (5): 79-84. https://www.researchgate.net/publication/264840864_Dynamics_Of_ Stock_Market_Return_Volatility_Evidence_From_The_Daily_Data_ Of_India_And_Japan

[8]Banerjee, A. and Sarkar, S. (2006), "ModelingdailyVolatility of the Indian Stock Market using intra-dayData", Working Paper Series No. 588, Indian Instituteof Management Calcutta.

[9] Binder,J.J., (1998). The Event Study Methodology Since 1969, Review of 19 Quantitative Finance and Accounting, Vol. 11 , 111137, https://link.springer.com/article/10.1023/A:1008295500105

[10] Bollerslev (1986) Generalized Autoregressive ConditionalHeteroskedasticity Journal of Econometrics 31 (1986) 307-327. North-Holland

[11] Brad. M., Barber. J. D., \& Lyon., (2007). Detecting long-run abnormal Journal of Financial Economics Volume 43, Issue 3, March 1997, Measuring its Interaction with Macroeconomic Variables: Indian stock returns: The empirical power and specification of test statistics,

Pages

$341-372$

https://www.sciencedirect.com/science/article/pii/S0304405X960089 02

[12] Corrado, C.J., (1989). A nonparametric test for abnormal security-price performance in event studies, Journal of Financial Economics, Volume 23, Issue 2, 385-395. https://www.sciencedirect.com/science/article/pii/0304405X8990064 0 .

[13] Coutts, J.A., Mills., T.C. \& Roberts, J., (1995). Testing cumulative prediction errors in event study methodology, 10.1002/for.3980140204. https://onlinelibrary.wiley.com/doi/abs/10.1002/for.3980140204

[14] Dima Alberg and Haim Shalit (2008) Estimating stock market volatility using asymmetric GARCH models, Applied Financial Economics, 2008, 18, 1201-1208

[15] Eberhart, A.C., Maxwell, W.F., \& Siddique. A.R., (2004). An Examination of Long-Term Abnormal Stock Returns and Operating Performance Following R and D Increases, The journal of finance The journal of the American finance association Vol. 59, No. 2,623-650, https://www.jstor.org/stable/3694909?seq=1\#metadata_info_tab_cont ents

[16] Fereshteh , Hossein (2013), International Journal of Scientific \& Engineering Research, Volume 4, Issue 11, November-2013 1785 ISSN 2229-5518

[17] Floros, Christos (2008), Modelling volatility using GARCH models: evidence from Egypt and Israel.Middle Eastern Finance and Economics (2). pp. 31-41. ISSN 1450-2889

[18] Frooman, J., (1997) Socially Irresponsible and Illegal Behaviour and Shareholder Wealth A Meta-Analysis of Event Studies. http://journals.sagepub.com/doi/10.1177/000765039703600302

[19] Glen.R (2005)volatility forecasts, trading volume, and the Arch Versus option-implied volatility trade-off, The Journal of Financial Research • Vol. XXVIII, No. 4 • Pages 519-538 Winter 2005

[20] Glosten, L. R., Jagannathan, R., and Runkle, D. E. (1993), "On the Relation between the Expected Value and the Volatility of the Nominal Excess Return on Stocks", Journal of Finance, Vol. 48 (5), pp. 1779-1801.

[21] Hazem A. S., \& Mohamed K.A.J., (2015). Trading Volume and Stock Returns Volatility: Evidence from Industrial Firm of Oman, Asian Social Science, Vol. 11, No. 24; 2015, 10.5539/ass.v11n24p139, http://www.ccsenet.org/journal/index.php/ass/article/view/47930

[22] Hirvonen, J., (2009). Abnormal stock performance induced by the establishing of Russian operations: An event study on a portfolio of Finnish companies. Kaikukatu: National Library of Finland https://www.doria.fi/bitstream/handle/10024/50656/nbnfi-fe2009121 72438.pdf

[23]Hock Guan Ng (2004) Recursive modelling of symmetric and asymmetric volatility in the presence of extreme observations International Journal of Forecasting 20 (2004) 115- 129

[24] Imelda, I., Siregar, H., \&Anggraeni, L., (2014). Abnormal Returns and Trading Volume in the Indonesian Stock Market in Relation to the Presidential Elections in 2004, 2009, and 2014. BISNIS and BIROKRASI: JurnalllmuAdministrasidanOrganisasi Vol 21, No 2 . http://journal.ui.ac.id/index.php/jbb/article/viewFile/4319/3184

[25] James, W., \&Pynnonen,K.S., (2010). Event Study Testing with Cross-sectional Correlation of Abnormal Returns. The Review of Financial Studies, Volume 23, Issue 11. https://academic.oup.com/rfs/article-abstract/23/11/3996/1605665

[26] Liu, Jinlin\& Switzer, Lorne N., (2009). Liquidity Risk, Firm Risk, and Issue Risk Premium Effects on the Abnormal Returns to New Issues of Convertible Bonds Available at SSRN: https://ssrn.com/abstract=1343597 http://dx.doi.org/10.2139/ssrn.1343597

[27] Jibendu Kumar (2010) Artificial Neural Networks - An Application To Stock Market Volatility, International Journal of Engineering Science and Technology Vol. 2(5), 2010, 1451-1460

[28] Jonsson, L., (2011). An empirical study of the impact of Opec announcements on stock returns of selected sector indexes of the Stockholm stock market, SodertornsHogskola Department for Economics ,Master Thesis 30pt, Finance, http://www.diva-portal.se/smash/get/diva2:442342/FULLTEXT01.pd 


\section{Stock Volatility in Muscat Securities Market}

[29] Kumar S. (2006) Comparative Performance of Volatility Forecasting Models in Indian Markets, Decis ion. Vol. 33, :Vo.2, July - D e c embe r , 2006Yung-Shi Liau\& Chun-Fan You 2013The transitory and permanent components of return volatility in Asian stock markets. Investment Management and Financial Innovations, Volume 10, Issue 4, 2013

[30] Malatesta, P.H., (1986). Measuring Abnormal Performance: The Event Parameter Approach Using Joint Generalized Least Squares, Volume 21, Issue 27-38 https://www.jstor.org/stable/2330988?seq=1\#metadata_info_tab_cont ents

[31] Mohandass (2013)Modeling volatility of bse sectoral indices international journal of marketing, financial services \& management research, issn 2277- 3622 Vol.2, no. 3, march (2013)

[32] Nalina, K., B., (2014). Stock market volatility a case study in Indian stock market, Published thesis, University of Mysore, Shodhganga: a reservoir of Indian theses @ INFLIBNET. https://www.researchgate.net/publication/321587753_STOCK_MAR KET_VOLATILITY_-_A_STUDY_OF_INDIAN_STOCK_MARKE $\mathrm{T}$

[33] Naliniprava (2013) Forecasting Stock Market Volatility: Evidence From Six Emerging Markets,Journal Of International Business And Economy (2013) 14(2): 69-93

[34] Neha Saini(2014) Forecasting Volatility in Indian Stock Market using State Space Models, Journal of Statistical and Econometric Methods, vol.3, no.1, 2014, 115-136 ISSN: 1792-6602 (print), 1792-6939 (online)

[35] Nelson (1991) Conditional Heteroscedasticity in Asset Returns: A New Approach, Econometrica, Vol.59, No.2 PP 347-370

[36] Philip (1996) Forecasting Stock Market Volatility Uisng (Non - Linear GarchModels,Journal of forecasting, Vol:15 pp 229-235

[37]PotharlaSrikanth(2014)Modeling Asymmetric Volatility in Indian Stock Market, Pacific Business Review International Volume 6, Issue 9, March 2014

[38]Prabhakaran., (2017). Forecasting Stock Price Volatility - An Empirical Study on Muscat Securities Market, International Journal of Applied Sciences and Management, Vol. 2, No. 2, 256-268, ISSN 2413-3396, https://www.waljatcollege.edu.om/journal/images/IJASM_020203.pd $\mathrm{f}$

[39] Prashant Joshi (2014) Forecasting Volatility of Bombay Stock Exchange International journal of current research and academic review - ISSN: 2347-3215 Volume 2 Number 7 (July-2014) pp. 222-230

[40]Praveen Kulshreshtha (2011) Volatility in the Indian Financial Market Before, During and After the Global Financial Crisis Journal of Accounting and Finance Vol. 15(3) 2015

[41]Qamruzzaman(2015) Estimating and forecasting volatility of stock indices using asymmetric GARCH models and Student-t densities: Evidence from Chittagong Stock Exchange, International Journal of Business and Finance Management Research, ISSN 2053-1842

[42] Qiang Zhang (2015) Global financial crisis effects on volatility spillover between Mainland China and Hong Kong stock markets Investment Management and Financial Innovations, Volume 12, Issue 1,2015

[43] Qiu,L., (2014). Earnings Announcement and Abnormal Return of S and P 500 Companies, Economics Department, Honours Thesis, March 18, 2014 http://citeseerx.ist.psu.edu/viewdoc/summary?doi=10.1.1.671.2834

[44]Rakesh Gupta (2012) Forecasting volatility of the ASEAN-5 stock markets: a nonlinear approach with non-normal errors Griffith University ISSN 1836-8123.

[45]Ravichandran, V. and Khalid Abdullah Alkhathlan (2010) Impact of Oil Prices on GCC Stock Market, Research in Applied Economics, ISSN 1948-5433, 2010, Vol. 2, No. 1: E4

[46]Shah, P. \& Arora, P., (2014). M and A Announcements and Their Effect on Return to Shareholders: An Event Study, Accounting and Finance Research, Vol 3, No http://www.sciedu.ca/journal/index.php/afr/article/view/4684

[47]Suman., (2011). Stock Market Volatility in Developing countries, Published thesis, MaharshiDayanand University, Shodhganga: a reservoir of Indian theses @ INFLIBNET. http://hdl.handle.net/10603/7858

[48]Tamilselvan, M. \&ShaikMastan Vali (2016) Forecasting Stock Marke Volitility- Evidence from Muscat Security Market Using GARCH Models, International Journal of Commerce and Finance, Vol. 2, Issue 1, 2016, 37-53

[49]Thompson, R., (1985). Conditioning the Return-Generating Process on Firm Specific Events: A Discussion of Event Study Methods, Journal of Financial and Quantitative Analysis. Vol. 20, No. 2 (Jun., 1985), pp $151-168$

https://www.jstor.org/stable/2330952?seq=1\#metadata_info_tab_cont ents

[50] Warner, J.R \& Brown, S.J., (1985). Using Daily Stock Returns, Journal of Financial Economics. Volume 14, Issue 1, 3-31 https://www.sciencedirect.com/science/article/pii/0304405X8590042 $\mathrm{X}$ ?via\%3Dihub 